\title{
Plaaslike ekumene en die einddoel van die eenheidstrewe
}

A G S Gous

\begin{abstract}
Local ecumenism and the goal of the ecumenical endeavour

According to the author the need for local ecumenism arises from the fact that nowadays there is not only the one universal church in many localities as in the early church but a new reality of many churches in one locality - a situation unknown to the New Testament. The quest for unity should therefore primarily originate from the local congregation. Gous clarifies the concept "local" and defines the ecumenical activity as such. He describes and evaluates five models for church unity: (i) organic unity, (ii) conciliar fellowship, (iii) reconciled diversity, (iv) communion of communions, and (v) unity as solidarity. He closes his article by listing reasons why churches remain caught in a situation of mutual exclusiveness, instead of full communion. A distorted relationship between unity and truth is one of the primary reasons.
\end{abstract}

\section{INLEIDING}

Ekumene is primèr die taak van die plaaslike gemeente en daarom nie net die opgaaf van enkele kerkleiers wat afgevaardig word na nasionale of wereldwye konferensies nie. Hierdie stelling word vervolgens teologies gemotiveer en daar word ook gefokus op modelle vir kerkeenheid wat die einddoel van die eenheidstrewe wil aandui. Struikelblokke op die weg na eenheid kry laastens aandag.

EEN UNIVERSELE KERK OP BAIE PLEKKE

Die kerk van Christus bestaan nie in die lug nie, maar fisies sigbaar in die geskiedenis op 'n spesifieke plek. Paulus se algemene sendbriewe is gerig aan 'n spesifieke adres: gemeentes "in Efese, Korinthe, Filippi, Kolosse" met die verdere kwalifikasie "in Christus". Guthrie sê hieroor: "There are two main ways in which Paul refers to the church. In most of his epistles it is the community of believers in a specified locality. The Corinthian correspondence is adressed to the church of God which is at Corinth' (1 Cor 1:2; 2 Cor 1:1). A similar formula is found in the Thessalonian letters, ... It is clear that the word 'church' was, therefore, used in the sense of a group of believers in a stated locality"1. Die kerk dui tweedens vir Paulus op die universele kerk, veral in Efesiërs 1:22 en Kolossense 1:18 waar dit oor Christus as hoof van die kerk gaan. 'n Vroeëre beleidsdokument van die Ned Geref Kerk beskryf die kerk soos volg: "Universeel omvat dit diegene uit die hele mensheid soos hulle deur die evangelie vergader word (Kol 1:23). Die kerk is die verloste mensheid in Christus, die tweede Adam (Rom 5:12-18; 1 Kor 15:45). In die partikuliere sin sien die kerk op die plaaslike gemeente of kerk (in geografiese sin). Elke plaaslike kerk is ' $n$ openbaring van die liggaam van Christus op ' $n$ bepaalde plek"2. Sowel die plaaslike as universele aspekte van die kerk moet hiervolgens ewe veel gewig dra. 
Voorts stel Guthrie ${ }^{3}$ en Durand ${ }^{4}$ dat die plaaslike kerk as openbaring van die algemene kerk op 'n bepaalde plek, in die volle sin van die woord kerk is: 'n ecclesia completa. Dit bring ons by die vraag na die verhouding tussen die plaaslike en algemene kerk (ekumeniese ekklesia). Indien 'n plaaslike kerk ekklesia in die volle sin van die woord is, is dit dan nog nodig dat hy die bestaan van die algemene kerk in ag moet neem? Volgens Durand ${ }^{5}$ is die plaaslike kerk slegs as 'n ecclesia particularis 'n volwaardige kerk en moet die sigbare eenheid van die ecclesia universalis nie uit die oog verloor word nie. Die plaaslike kerk verwerklik slegs op klein skaal die kerk as geheel. Die plaaslike kerk is dus kompleet kerk, maar nie in independentistiese sin nie. Volgens Jonker 6 is die gereformeerde reaksie hierop dat daar 'n kerkverband tot stand moet kom wat die gemeenskap van die gelowiges moet struktureer en dien: "Die gereformeerde begrip van kerkverband... gaan 'n eie weg tussen die independentisme aan die een kant en die hiërargiese eenheidstruktuur van die katolisisme aan die ander kant. Dit skep die struktuur wat nodig is vir die onderlinge sorg van die verskillende plaaslike kerke vir mekaar soos die Nuwe Testament ons dit laat sien en is in wese niks anders nie, as 'n gestalte van die communio sanctorum self". Ekumeniese kontak (wêreldwyd of landswyd) tussen gemeentes behoort dus 'n permanente opgaaf op die agenda van enige gemeente te wees.

BAIE KERKE OP EEN PLEK?

As daar egter net een kerk op aarde was sou die enigste ekumeniese probleem die verhouding tussen die plaaslike en universele kerk gewees het. Ongelukkig het 'n nuwe werklikheid op die toneel verskyn. Ons het vandag nie meer net te doen met die één kerk op baie plekke nie, maar ook met baie kerke op een plek. Durand ${ }^{7}$ noem dit die "onmoontlike werklikheid" van 'n gedeelde kerk. Die onmoontlikheid lê daarin dat daar nou op een en dieselfde plek meer as een "liggaam van Christus" is (1 Kor 12:12-13; Ef 4:12; Rom 12:4-5; Kol 1:18), of anders gestel, dat daar in dieselfde voorstad tien of meer hruide (kerke) vir dieselfde bruidegom (Christus) is (2 Kor 11:1 ev).

Die hele idee van 'n veelheid van kerke lê buite die gesigsveld van die Nuwe Testament. Wanneer die Nuwe Testament die meervoud ekklesiai gebruik, word daarmee die plaaslike kerke aangedui, maar hierdie plaaslike kerke is almal openbaringe van die één kerk van Christus op spesifieke plekke, sodat hulle meervoudigheid nie beteken dat Christus meer as een kerk het nie. Daar kan volgens die Nuwe Testament slegs één kerk wees, omdat die kerk die liggaam van Christus is, en Christus tog nie meer as een liggaam kan hê nie ${ }^{8}$. Hiermee as uitgangspunt roep die bestaan van verskillende denominasies/kerke op presies dieselfde plek na aanleiding van Kolossense 1:18 die drogbeeld op van - nie 'n veelkoppige monster nie, maar - 'n onmoontlike wese met een kop/hoof en baie lywe. Of erger gestel: die bestaan van baie kerke/denominasies op dieselfde plek laat Christus in die oë van die wêreld na 'n veelwywer lyk (na aanleiding van 2 Kor 11:1 ev) - 'n ernstige aanklag teen die kerke. Christus se geloofwaardigheid word hierdeur aangetas (Joh 17:21) en die werklikheid van 'n verskeurde kerk roep om regstellende aksie. Bavinck ${ }^{9}$ het hierdie punt al jare gelede ingesien: "Wij kunnen ons als Christenen niet diep genoeg verootmoedigen over de scheuring en twee-dracht, die alle eeuwen door in de kerk van Christus heeft bestaan; zij is eene zonde tegen God, in strijd 
met de bede van Christus, en veroorzaakt door de duisternis van ons verstand en de liefdeloosheid van ons hart".

Heyns $^{10}$ som die situasie goed op: "Naas die verskeidenheid van kerke gebaseer op die verskeidenheid van lokaliteite, vind ons egter ook 'n verskeidenheid van kerke gebaseer op en as openbaring van 'n verskeidenheid van konfessies. Hoe die uiteenlopende verstaan van die Skrif en die neerslag daarvan in verskillende konfessionele oortuiginge verteenwoordig deur verskillende kerke ookal positief gedui mag word as 'n aanduiding van die betekenisrykdom van die Skrif, ten diepste moet dit tog met die verduisterende werking van die sonde in verband gebring word. As sonde moet dit dan ook gesien, behandel, en betreur word. Maar dan moet dit aanvaar word dat ook hierdie sonde deur Christus oorwin is, en deur ons, in die krag van die Gees, bestry moet word. Ekumenisiteit, vanuit hierdie gesigspunt besien, is gevolglik die institutêre kerk se konkrete stryd teen sonde". Die kerk moet dus in beweging kom en daarom geld die oproep van Bavinck ${ }^{11}$ vandag nog:

"Sedert de Reformatie is de kerk overgegaan in de periode der pluriformiteit; en dit feit dwingt ons, om de eenheid der kerk veelmeer ... te zoeken".

Hierdie soeke na eenheid vind ons in die wêreldwye ekumeniese beweging wat eenheid oor kerkgrense heen soek. Dit het uitgeloop op die stigting van die Wêrełdraad van Kerke in 1948, as interkonfessionele ekumeniese organisasie. Die twintigste eeuse ekumeniese beweging is reeds in die vorige eeu voorafgegaan deur die stigting van wêreldwye liggame vir die verskillende konfessies soos die Wêreldbond van Gereformeerde Kerke (WBGK), die Lutherse Wêreldfederasie (LWF), die "World Methodist Council" en die "Anglican Consultative Council" (Lambeth Conference). Die soeke na die herstel van die eenheid op topvlak tussen kerkleiers het dus reeds 'n lang geskiedenis. Hierdie soeke moet egter ook veral op plaaslike vlak geskied omdat die verskillende kerke se geboue wat naby mekaar staan in die dorpe en voorstede, sigbaar aan elke verbyganger getuienis lewer van 'n verskeurde kerk. Tydens die Lausanne byeenkoms in 1974 het dr Jonathan Tien-en Chao van Hong Kong die probleem soos volg beskryf: "The real issue confronting evangelicals worldwide today is not so much finding out the nature of the unity of the local church in relation to the universal church as the body of Christ, but understanding the nature of the unity among local churches within a given locality"12. Die dringende vraag wat ons vandag al meer ook in Suid-Afrika moet vra is, weer in die woorde van Chao: "What should be the unity of the people of God in the twenty-odd congregations that belong to seven or eight different denominations...in that town"13. Gegewe die werklikheid van verskeurdheid kan ons sê dat 'n plaaslike gemeente wat nie ekumenies betrokke raak nie aan 'n "onheilige vergeetagtigheid" ly - wat vergeet dat daar ook broers en susters in ander kerke is omdat ons almal kinders van dieselfde Vader is. So 'n kerk leef dan asof hy/sy die enigste kerk van Christus op ' $n$ bepaalde plek is. Tydens 'n informele ekumeniese byeenkoms vir plaaslike kerke in Waterkloof, Pretoria op 28 Oktober 1990 waar David Bosch die spreker was, sè hy: "Most of us have, in a sense, been living and working in our own little ghettos, catering for our own clientèle and doing our own thing. We had 
linkages with our denominations in the wider context of the city and the country, but appeared to be oblivious of those brothers and sisters literally just around the corner"14. Volgens 'n verslag van die Nederlandse Hervormde Kerk van 1974 is "de oecumenische gestalte van de gemeente" een aspek van kerkwees:

"Al lijkt het, dat elke kerk volledig en zelfstandig kan bestaan, zij kan dat alleen in een onheilige vergeetachtigheid, in het wegdringen van het besef van schuld, in een afweren van elke nieuwe ontmoeting. Maar in de onaangevochten vanzelfsprekenheid, waarin een kerk haar aparte bestaan heeft, gaat het geheim van de gemeente verloren. Daarom hoort tot het geheim van de gemeente ook haar oecumenische gestalte"15.

Die houding van 'n plaaslike gemeente behoort een te wees van 'n "deemoedige pretensie": "De pretentie is: wij zijn voor ons deel het gehéel; de deemoed is: wij zijn het geheel slechts voor ons deel. De oecumenische gestalte van de gemeente is, dat zij voortdurend het geheel van het volk van God in het oog houdt en wil vertegenwoordigen"16. 'n Gemeente van 'n spesifieke kerk op 'n spesifieke plek mag dus nie in selfgenoegsaamheid in homself gekeerd bly bestaan nie en ook nie arbei in die koninkryk asof dit die enigste kerk van Christus is wat bestaan nie. Die plaaslike gemeente sal dus tesame met gemeentebou in eie geledere, ook 'n oog moet ontwikkel vir die eenheid en opbou van die breë liggaam van Christus. "Liggaamsbou" sal dus net so deel van die plaaslike gemeente se agenda moet wees as gemeentebou en die uitbou van die koninkryk. Skematies kan dit so voorgestel word: 17

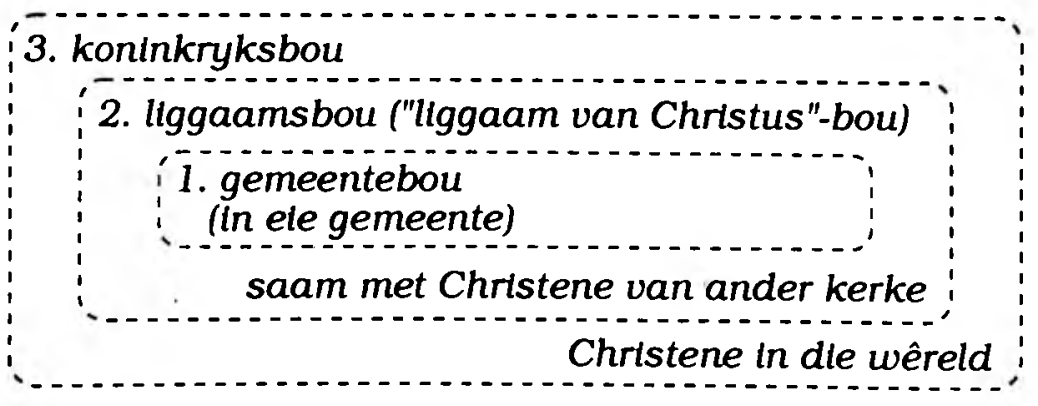

Die geperforeerde lyne impliseer dat die eenheid en opbou van die breë liggaam van Christus op 'n spesifieke plek, ook invloed gaan hè op die koninkryk en op die opbou van die plaaslike gemeentes van die verskillende kerke. Kontak met ander Christene se perspektiewe en handelswyses kan vernuwing tot gevolg hê in die eie gemeente - mits daar 'n openheid is om by mekaar te leer en 'n onderskeidingsvermoë om slegs die goeie te inkorporeer. Wanneer Christene/kerke verder ook as eenheidsfront die wêreld in beweeg om sy koninkryk te laat kom, kan dit nie anders as om verandering tot gevolg te hê nie. Chao noem dit: "...the tremendous challenge 
for unity in body-building and evangelism on a limited regional level" 18 .

Om op te som: die tweeledige werklikheid van een kerk (konfessie) op baie plekke en baie kerke (konfessies) op een en dieselfde plek noop die kerk om betrokke te raak by twee tipes ekumene, naamlik: (1) Konfessionele ekumene op plaaslike, landswye en wêreldwye vlak. (2) Interkonfessionele ekumene (insluitende alliansie-ekumene) op plaaslike, landswye en wêreldwye vlak. Die huidige werklikheid in Suid-Afrika van rasgeskeide kerke noop die kerk ook tot 'n derde tipe "ekumene" wat ek (3) intra-kerklike of familie-ekumene noem. Die feit dat die Gereformeerde, Presbiteriaanse en Lutherse tradisies in die verlede aparte kerke vir verskillende rassegroepe gestig het, het tot gevolg dat een denominasie tot vier aparte kerke (behorende tot dieselfde denominasie/familie) in dieselfde land of geografiese gebied het. Plaaslike ekumene moet dus ook hierdie derde werklikheid van een kerk se rasgeskeide kerke wat ongeveer op dieselfde plek bestaan, in ag neem. Die geskiedenis van vestiging en kerkplanting in Suid-Afrika het die kerk hier te lande ook nog gelaat met die stuk historiese bagasie van skeiding tussen die sogenaamde "Afrikaanse kerke" en "Engelssprekende kerke"19. Hoewel hierdie onderskeid veels te breed en nie waterdig is nie, verwys dit tog na 'n werklikheid van taal en kulturele grense wat ook op plaaslike vlak aangespreek moet word. Selfs kerke wat konfessioneel ooreenstem, soos byvoorbeeld die Ned Geref Kerk en die Presbiteriaanse Kerk, word deur hierdie taalgrens vanuit die geskiedenis geskei.

Daar bestaan groot eenstemmigheid oor die belang van plaaslike ekumeniese betrokkenheid by baie skrywers ${ }^{20}$. Bosch ${ }^{21}$ gaan selfs so ver om te sê: "The litmus test for the ecumenical movement is what happens where local churches live and minister". Daar is egter nie altyd duidelikheid, of selfs eenstemmigheid wat presies met die term "plaaslik" bedoel word nie. Tydens 'n werkswinkel oor die Ned Geref Kerk se ekumeniese beleid en praktyk in 1992 is daar onder andere beraadslaag oor hoe ver die grense van "plaaslike" ekumene strek: gemeente, ring, voorstede, dorp/stad, streek, provinsie? "Hoe hanteer 'n mens plaaslike ekumene in 'n gebied waar daar byvoorbeeld een Anglikaanse, twee Presbiteriaanse, een Baptiste, een Gereformeerde, een Hervormde, een Rooms Katolieke en vyf Ned Geref Gemeentes bestaan? Wie skakel met wie? Behoort 'n groep Ned Geref gemeentes (ring?) saam betrokke te raak by die stigting van 'n informele 'Komitee vir Plaaslike Kerke' saam met al die ander kerke in die omgewing? Indien daar geen NGKA, Ned Geref Sendingkerk of RCA gemeente naby (in die plaaslike radius) is nie, beteken dit dat daar nie met hulle geskakel moet word nie? Moet die gemeente as die kleinste eenheid vir plaaslike ekumene beskou word in die lig daarvan dat sekere kerke met 'n hiërargiese gesagstrukıuur (soos die RKK) die bisdom en nie die gemeente nie, as die kleinste gesagsdraende eenheid beskou?"22

Volgens Keshishian ${ }^{23}$ spesifiseer die Nuwe Testament nie die gebieds. grootte van die plaaslike kerk nie. Aanvanklik was die plaaslike kerk diegene wat in nagmaalsgemeenskap met mekaar is, hetsy in 'n "polis", stad of later met die ontwikkeling van die kcrklike hiërargie selfs 'n streek. Die kortste antwoord op die vraag is in 1961 tydens die New Delhi algemene vergadering van die WRK beskryf as "almal (alle christene) in een plek" 24 . 'n Meer bevredigende en volledige antwoord sal drie aspekte in ag moet neem: 
Die ekklesiologieë van die verskillende kerke op dieselfde plek. Keshishian gee 'n goeie uiteensetting 25 :

- die kerke met 'n biskoplike stelsel (hiërargiese kerke soos die Rooms Katolieke, Ortodokse, en Anglikaanse kerke) beskou die plaaslike kerk as die bisdom ("diocese") onder leierskap van 'n biskop. Gemeentes ("parishes") is dan subeenhede van die geheel. Die plaaslike eenhede tree in verhouding met mekaar deur die onderlinge erkenning/gemeenskap van die biskoppe.

kerke met 'n presbiteriale stelsel beskou die gemeente ("parish") as die plaaslike kerk; daar waar presbiters/ouderlinge regeer. Verhoudinge met ander plaaslike gemeentes word deur middel van sinodale verband gehandhaaf.

- die kongregasionalistiese model beskou uiteraard ook die gemeente as die plaaslike eenheid en tree gemeente tot gemeente met mekaar in verhouding.

Uit die gereformeerde oogpunt sal plaaslike ekumene dus vanuit die gemeente beoefen word. Informeel kan daar met ander gemeentes van alle kerke geskakel word. Wanneer daar egter sprake is van meer formele ekumeniese kontak, veral met die hiërargiese kerke, sal die gereformeerde kerke ekumene vanuit hulle ringsvergaderinge moet bedryf. Die feit van 'n verskeurde kerk maak dat die werklike plaaslike kerk eintlik bestaan uit al die kerke (met hulle verskillende ekklesiologieë) op 'n bepaalde plek.

(ii) Die plek/lokaliteit van die kerke en die reikwydte van verskillende kerke se gemeente grense. Die oorvleuelende gemeentegrense van die verskillende kerke wat nie ooreenstem nie, moet in ag geneem word en 'n breë konsensus moet bereik word oor watter gebiede saam hoort. Volgens Keshishian is "plek" egter nie net 'n geografiese werklikheid nie, maar ook 'n eksistensiële werklikheid wat etniese, kulturele, sosiale, politieke en konfessionele aspekte moet insluit ${ }^{26}$.

(iii) 'n Derde aspek is die ampte in die kerk. Die hele doel van plaaslike ekumene kan weer verlore gaan as dit net kerkleiers of predikante/priesters/pastore betrek. Die "plaaslik" in plaaslike ekumene dui juis daarop dat die amp van die gelowige direk daarby betrokke moet wees. Eers wanneer gewone kerklidmate betrokke is, het plaaslike ekumene grondgevat. Sodoende word verhoed dat ekumene slegs die spel van enkele kerkleiers bly wat afgevaardig word na nasionale of wêreldwye konferensies.

Die term "plaaslik" bly dus steeds 'n vaag gedefinieerde term wat met inagneming van bogenoemde, in elke situasie weer opnuut bepaal moet word. Dit kan selfs op 
landswye ekumene dui. Meestal dui dit egter op al die kerke in 'n dorp, stad of 'n aantal voorstede.

PLAASLIKE EKUMENE: DIE AKTTWITEIT GEDEFINIEER

Vervolgens moet klarigheid verkry word oor wat verstaan word onder die aktiwiteit ekumene wat plaaslik moet plaasvind. Wat doen'n kerk wat ekumenies betrokke is? Die antwoord is implisiet reeds gegee, naamlik "liggaamsbou" in samehang met gemeentebou en koninkryksbou. Dié aktiwiteit moet egter eksplisiet verder gedefinieer word. Nou verwant hiermee is die vraag na die einddoel van hierdie aktiwiteit. Waarna mik die eenheidsoeke?

Van der Walt ${ }^{27}$ beroep hom soos volg op die Skrif om die aktiwiteit van eenheidsoeke te omskryf: "so kom ook die eenheid van die Kerk op allerlei wyse tot uitdrukking, soos onderlinge liefde teenoor mekaar (1 Kor 4:7-11, 20-21), eenheid van die geloof en van die kennis van die Seun van God (Ef 4:13), een hoop van ons roeping (Ef 4:4), wedersydse hulp van plaaslike kerke (2 Kor 8 en 9), wedersydse diensbetoning (Rom 12:13), deelname aan mekaar, sy lyding en laste (Gal 6:2, Fil 2:1, Fil 4:14, Heb 10:33), eendragtige getuienis teenoor die wêreld (vgl Joh 17:21), gemeenskaplike optrede (Rom 15:26; 2 Kor 8:19), die ontvangs van mekaar se lede (Rom 16:1-2), en gemeenskaplike beraadslaging met bindende besluite (Hand 15)". Uiteraard is die saak hiermee nog nie afgehandel nie, omdat die Nuwe Testament nie die hedendaagse werklikheid van 'n veelheid van kerke ken nie. Ekumeniese aktiwiteit vandag moet ook gerig word op die feit van 'n verskeurde kerk. Volgens die Nederlandse Hervormde Kerk gaan dit, wat die verskeurde kerk betref, in die eerste instansie nie om 'n formele fusie van die verskillende kerke nie, "maar om een proces van elkaar kennen, herkennen, erkennen, om groei naar een zichtbare eenheid. Dat houdt in: verzoening (na vele jaren van vervreemding), vernieuwing (wij leren van elkaar), verbinding (wij vinden elkaar in de opdracht te midden en ter wille van de anderen). Daarin voltrekt zich de eenheid, die Christus voor zijn gemeente vraagt aan de Vader (Joh 17) 28.

Volgens Jonker ${ }^{29}$ kan die eenheid tussen die verskeurde kerke die gestalte aanneem van eenheid in belydenis, diens, gebede, gemeenskap en getuienis. Dit kan ook die wedersydse erkenning en aanvaarding van mekaar se ampte en lidmate insluit. "Hierdie vorme van eenheid is uiters betekenisvol, omdat dit almal daarop gerig is om die communio sanctorum te dien. Dit hou verband met verskillende institutêre elemente in die lewe van die kerke, maar dring tog nie daarop aan dat daar net een kerklike instituut tot stand moet kom nie. Natuurlik word dit nie uitgesluit nie. Die moontlikheid bestaan dat kerke na mekaar toe kan groei en dat daar uiteindelik wel tot institutêre eenheid besluit sal kan word, maar dit is dan 'n eindpunt, nie 'n beginpunt nie". Bondig gestel, kan ons saam met Sullivan sê30: "Ecumenism is a movement towards church unity by stages. Of course it is much more. But the concern for true church unity remains at the center of the movement". In 'n poging om die voorafgaande argumentasie te kristaliseer volg hier nou ' $n$ werksdefinisie vir ekumene wat die aktiwiteit definieer. Hierdie definisie is 'n uitbreiding op 'n vorige poging ${ }^{31}$ en inkorporeer ook insigte uit die volgende afdeling wat handel oor die einddoel van die eenheidstrewe:

Ekumene in die algemeen asook plaaslike ekumene is daardie beweging waarin elke kerk en die individuele Christen as deel van die liggaam van Christus, 
die ander kerke en medegelowiges in Christus oor grense (taal-, konfessionele-, geografiese-, kulturele-, ideologiese- en kleurgrense) heen opsoek, om (a) die opbouende ervaring van die gemeenskap van die gelowiges te ervaar; (b) binne die kerk (gemeenskap van die gelowiges) saam met alle ander Christene te soek na en te getuig van die waarheid van Gods woord in teks en konteks, en (c) die eenheid van die kerk in getuienis en diens aan die wêreld sigbaar te toon sodat die wêreld kan glo in Jesus Christus en Hom ook begin dien.

\section{Ekumeniese aktiwiteit behels:}

1. gesprek (wat verkennend, korrigerend, opbouend en ondersteunend van aard kan wees of met die oog op versoening of vernuwing); 2 . gesamentlike gebed; 3 . samewerking; 4 . gesamentlike belewenis/gemeenskap; 5 . gesamentlike getuienis; 6 . diens- en hulpaksies; 7 . beraadslaging en raadpleging in skakelstrukture (met of sonder bindende besluite); 8 . konsiliêre vergaderings (met bindende beshite vir die hele kerk); en 9. eenwording met medegelowiges.

\section{6}

\section{DIE EINDDOEL VAN DIE EENHEIDSTREWE}

Vanselfsprekend het die eenheidsoeke 'n algemeen aanvaarde en duidelik gedefinieerde doel nodig om enigsins te vorder. Dit was ook die slotsom van die Nairobi vergadering van die Wêreldraad van Kerke se afdeling oor "What unity requires"32. Veral Suid-Afrika, wat 'n post-apartheid era binnegaan, het dringend behoefte aan 'n omvattende model vir die eenheid van al die kerke in die land, wat die apartheidsreste in die kerke en die eeuelange konfessionele verskille asook regmatige bedieningsbehoeftes en die verskeidenheid van gawes kan aanspreek. Die SuidAfrikaanse Raad van Kerke kan instrumenteel wees hierin mits die groot aantal kerke wat buite sy geledere staan, betrek word by so 'n proses. Tydens ' $n$ konsultasie vir nasionale rade van kerke (die sg NCCs) in Genève het Legrarde voorgeste! dat dergelike rade nouer betrokke moet raak by die opheldering van die doel, oftewel die aard van die eenheid wat hulle lidkerke soek ${ }^{33}$. Die debat binne SuidAfrika oor die doel van ekumene sal veral moet sentreer rondom die bestaande modelle vir kerkeenheid wat reeds elders in die wêreld uitgekristaliseer het, en waarvan daar heelwat in omloop is. Een model waarvan die ekumeniese beweging hom egter baie gou van gedistansieer het, is die "superkerk"-model. Hoewel daar geen twyfel daaroor bestaan dat die oorspronklike doel van die ekumeniese beweging die totale eenheid van die kerke is nie ${ }^{34}$, het die Sentrale Komitee van die Wêreldraad van Kerke in Toronto in 1950 reeds 'n verklaring uitgereik "Wat die WRK nie is nie". Bo aan die lys staan: "Die WRK is nie en wil nie 'n 'superkerk' wees nie"35. Daarmee is die model van een nuwe monolitiese struktuur vir al die kerke afgewys, ${ }^{36}$ sonder om organiese eenheid as einddoel uit die oog te verloor. Eie aan die ekumeniese beweging wat uitmunt in die munt van nuwe frases, formules of leuses dra die modelle wat sedert die organiese eenheid-model ontwikkel het name soos "konsiliêre gemeenskap", "eenheid in versoende verskeidenheid" en "gemeenskap van gemeenskappe". Hierdie frases is gelaaide teologiese konsepte wat heelwat ekklesiologie in hulle saamdra 37 . Hierdie modelle is nie noodwendig wedersyds uitsluitend nie, hoewel daar belangrike verskille tussen hulle bestaan. 
Die tweede wèreldkonferensie oor "Faith and Order" te Edinburgh in 1937 het organiese eenheid reeds as doel gevisualiseer ${ }^{38}$. Heelwat kerke (meer as sestig in totaal) het sedert ongeveer 1925 hulle denominasionele identiteit prysgegee en opgegaan in 'n meer inklusiewe verenigde kerk. Die bekendste is seker dié van Suid-Indië (1947) wat die Metodiste, Anglikane, Presbiteriane en Kongregasionaliste en ander protestante verenig het ${ }^{39}$. Elders in die wêreld het die genoemde kerke asook Lutherane en Gereformeerdes verenig. Die Rooms Katolieke en Ortodokse kerke het nog nooit deelgeneem aan so 'n kerkvereniging nie. Organiese kerkeenheid as model het sy meeste steun beleef ná 1961. Tydens die New Delhi vergadering (1961) het die Wèreldraad van Kerke gepoog om "die aard van ons gesamentlike doel ... die visie vir die een kerk wat die inspirasie is vir ons ekumeniese aktiwiteit" te formuleer. Die kern van die New Delhi-formulering behels dat die eenheid van die kerk "...is being made visible as all in each place ...are united with the whole Christian fellowship in all places and all ages ...in such wise that ministry and members are accepted by all, and that all can act and speak together as occasion requires for the tasks to which God calls his people ${ }^{\prime 40}$. Die verwysing na "almal in elke plek" en na "alle plekke en tye" dui daarop dat die outentieke eenheid plaaslike en universele eenheid insluit. Die impak van die visie blyk uit die feit dat daar tussen New Delhi (1961) en die volgende vergadering van die Wereldraad van Kerke in Uppsala (1968) meer as twintig verenigde kerke tot stand gekom het ${ }^{41}$. Dié model vra nie noodwendig eenvormigheid van organisasie, rites en ervaringsvorme nie ${ }^{42}$. Dit is nie 'n statiese organisatoriese samesmelting nie, maar ' $n$ lewende eenheid 43 wat ruimte wil laat vir outentieke verskeidenheid binne ' $n$ raam van outentieke eenheid en gemeenskap ${ }^{44}$. Wat organiese eenheid vra, is duidelik uitgespel in 1970 tydens 'n konferensie vir verenigde en verenigende kerke in Limuru, Kenia: "A common basis of faith; a common name; full commitment to one another, including the readiness to give up separate identity; the possiblity of taking decisions together and of carrying out the missionary task as circumstances require" 45 .

Die model dien ook as basis vir kerkverenigings binne dieselfde konfessie. Drie Lutherse kerke in Amerika het byvoorbeeld in 1987 saamgesmelt tot die nuwe "Evangelical Lutheran Church in America"46. 'n Verdere voorbeeld is die verenigingspoging tussen die Nederlandse Hervormde Kerk (NHK) en die Gereformeerde Kerke in Nederland (GKN). Die twee kerke het in die sewentigerjare besluit om te verenig 47 en 'n proses op tou gesit genaamd "Samen op weg". Dit was/is 'n langsame tog met stadige, dog goeie vordering en die twee verenigende kerke (insluitende die Evangelies-Lutherse Kerk) hoop om teen Januarie 1996 'n verenigde kerk te wees ${ }^{48}$. In Suid-Afrika kan organiese kerkeenheid as model dien vir die binnelandse lede van die "familie" van Ned Geref Kerke. Twee van die vier kerke, naamlik die Ned Geref Sendingkerk en die Ned Geref Kerk in Afrika het reeds die pad begin loop om 'n verenigende kerk te stig. Die twee kerke kon nie daarin slaag om die verenigingspoging soos beplan in ' $n$ japtrap af te handel nie. Die vroegste datum, kerkregtelik gesproke, waarop dié twee kerke die beplande "Verenigende Gereformeerde Kerk in Suider-Afrika" (VGKSA) kan stig, is volgens ds Russel Botman eers in Maart 1994 na die vervroegde sinode van die Ned Geref Sending- 
kerk $^{49}$. Die ideaal is egter dat al vier kerke so gou moontlik saam op weg moet gaan in ' $n$ nuwe omvattender verenigingspoging. Dit is 'n realistiese moontlikheid gesien in die lig van die Ned Geref Kerk beleidstelling in sy Ekumeniese Beleid 1.5.3 dat 'n eenheidsband dringend onderhandel moet word "vir die Ned Geref Kerk binne die Republiek van Suid-Afrika..."50. Die Reformed Church in Africa (RCA) het reeds ' $n$ abortiewe bi-laterale verenigingspoging met die Ned Geref Sendingkerk beleef, wat ' $n$ ernstige skeuring tot gevolg gehad het in RCA geledere. Die RCA is nie weer bereid tot enige bi-laterale verenigingspoging nie. Eenheid tussen die Nederduitsch Hervormde Kerk, die Gereformeerde Kerk en die Ned Geref Kerk (die sg drie susterskerke) kan ook geskied aan die hand van die organiese kerkeenheidmodel. Menslik gesproke lyk eenheid tussen hierdie drie kerke in SuidAfrika egter onwaarskynlik, veral omdat ongeveer vyftig jaar se onderhandelings tussen hierdie drie kerke in die Tussenkerklike Kommissie (TKK) (en sy voorgangers) nog niks konkreets opgelewer het nie. Die mislukking van die TKK is deels geleë in sy opdrag, naamlik dat die kerke dit waaroor hulle verskil onder oë moet neem in plaas van dit waaroor hulle saamstem.

Die model van organiese kerkeenheid het egter binne die ekumeniese beweging stelselmatig begin plek maak vir ' $n$ nuwe aanvullende model wat vervolgens bespreek word "... mainly because of the fear that organic unity could mean, for some churches at least, the development of structures that might hinder the diversity of Christian life ${ }^{n 51}$.

\subsection{Konsiliêre gemeenskap}

Hierdie model kan beskou word as 'n baie belangrike uitbreiding op die vorige model; "... a broadening of an overdemanding method of organic unity" 52 . Hierdie model visualiseer die eenheid as 'n "eenheid van plaaslike kerke wat in die volle sin van die woord verenig is". Die uiteindelike doel van dié model is 'n egte ekumeniese konsilie wat deur die hele kerk in die hele bewoonde wêreld en in die plaaslike konsiliêre gemeenskap aanvaar word. Die model het sy beslag gekry in 1973 tydens 'n konsultasie te Salamanca wat deur die "Faith and Order"-kommissie van die Wêreldraad van Kerke byeengeroep is: "Jesus Christ founded one Church. Today we live in diverse churches divided from one another. Yet our vision of the future is that we shall once again live as brothers and sisters in one undivided Church. How can this goal be described?... The one Church is to be envisioned as a conciliar fellowship of local churches which are themselves truly united. ... expressed in conciliar gatherings whenever required for the fulfillment of her common calling"53.

Hierdie model wil veral plaaslike kerke oor konfessionele grense heen versoen. In 'n verenigde kerk in konsilière gemeenskap is daar ruimte vir die voortbestaan van die verskillende konfessies en tradisies 54 . Die model vra vir verteenwoordigende konsiliêre vergaderings (lees: "konsilies") as strukture van gesamentlike besluitneming. In gevalle van gesamentlike besluitneming oor sake wat die leer, lewe en missie van die hele kerk raak, is die ideaal 'n ekumeniese konsilie in die ware sin van die woord gemodelleer op die (ongeveer sewe algemeen erkende) ekumeniese konsilies van ouds wat onder andere die triniteitsleer en die leer oor die twec nature van Christus geformuleer het.

Opklaring moet verkry word oor presies wat met die woord "konsilie" 
bedoel word55. Die Engelse woord "council" kan teologies gesproke op twee sake dui: (a) die verteenwoordigende vergadering van een verenigde kerk, byvoorbeeld: "ecumenical council"; of (b) die voorlopige gemeenskap van steeds verdeelde kerke, byvoorbeeld: "World Council of Churches".

Op Frans beteken "concile" die amptelike byeenkoms van een kerk en "conseil" die gemeenskap van verdeelde kerke. Die Frans vir Wêreldraad van Kerke is dan: "Conseil oecuménique des Eglises". Grieks gebruik die woorde "synodos" en "symboulion"; Duits: "Konzil" en "Rat" (WRK: "Ökumenischer Rat der Kirchen"); Italiaans: "concilio" en "consiglio"; Spaans: "concilio" en "consejo" (WRK: "Consejo Mundial de Iglesias"); Russies: "sobornost" en "sowjet" (vergelyk die Sowjet Unie van ouds) en Latyn met dieselfde woord "concilium" en "concilium". In Afrikaans word die woorde "sinode" of "konsilie" vir eersgenoemde betekenis (kyk (a)) gebruik en "raad" of "bond" vir laasgenoemde (kyk (b)), byvoorbeeld: Wêreldraad van Kerke; Wêreld-bond van Gereformeerde Kerke en die Gereformeerde Ekumeniese Raad (GER). Die onlangse naamsverandering van die Gereformeerde Ekumeniese Sinode na Gereformeerde Ekumeniese Raad is dus 'n aanduiding van 'n losser band wat nou tussen die kerke bestaan. Afrikaans leen hom tot 'n verdere onderskeid, naamlik dat "sinode" dui op die streeks-, landswye, of wêreldwye vergaderings van een denominasie. Wanneer al die kerke (denominasies) verenig is en vergader, word dit 'n konsilie genoem - 'n plaaslike, nasionale of ekumeniese (wêreldwye) konsilie. As ons hierdie onderskeid as uitgangspunt neem, is die vertaling van "Second Vatican Council" met "Tweede Vatikaanse Konsilie" ietwat pretensieus omdat dit die vergadering van een (weliswaar die grootste, maar nogtans slegs een) van die baie kerke in die wêreld met'n konsilie gelykstel.

Die woord "konsiliêr" verwys dus na die onderlinge verhouding van alle plaaslike kerke binne die een kerk van Christus. "Occasionally when major issues concerning the truth and the unity of the Church need to be faced, the need for universal councils may arise". Op plaaslike vlak "... (m)eeting in council is a discipline required by communion in Christ; a means of mutual edification and correction"56. Die einddoel van die ekumeniese beweging is daarom volgens hierdie model nie 'n Wêreldráad van (nasionale) Kerke nie maar 'n "Wêreldkonsilie van Plaaslike Kerke"! Konsiliêre gemeenskap as model vir eenheid, is amptelik deur die Nairobi Algemene Vergadering van die Wêreldraad van Kerke in 1975 aanvaar ${ }^{57}$. Die Bangalore vergadering van die "Faith and Order" - kommissie van die Wêreldraad van Kerke in 1978 het die debat verder gevoer en drie minimum voorwaardes vir konsiliêre gemeenskap gestel: Eerstens konsensus oor die algemene apostoliese geloof; tweedens die wedersydse erkenning van doop, nagmaal en bedieningspatrone en derdens die daarstel van strukture vir onderhandeling en gesamentlike besluitneming58. Die Sewende Algemene Vergadering van die Wêreldraad van Kerke in Canberra, Australië (1991) het konsiliêre gemeenskap as model vir eenheid herbevestig en wel in terme van "koinonia": "... full communion will be expressed on the local and the universal levels through conciliar forms of life and action..." ${ }^{59}$. Die Wêreldraad van Kerke self en nasionale rade van kerke is dus nie konsiliêre vergaderings nie, maar is in verhouding met die doel pre-konsiliêr. Georganiseerde ekumene op plaaslike vlak in Suid-Afrika is nog in sy kinderskoene (op enkele goeie uitsonderings na). Die Suid-Afrikaanse Raad van Kerke kan dalk, soos die Nasionale Ráad van Kerke in die VSA, meer klem lê op en steun verleen 
aan plaaslike ekumene via 'n "Commission on Regional and Local Ecumenism"60. Die volgende sake moet in ag geneem word by die vestiging van 'n konsiliêre gemeenskap en veral die byeenroep van konsilies:61 (i) Die geleentheid: byvoorbeeld in konfliksituasies; (ii) Territoriale omvang: plaaslik, streek of wêreld; (iii) Wanneer? Ad hoc of tydens vooraf vasgestelde datums; (iv) Sameroeper: kerkleiers, sekulêre gesag, op inisiatief van individue, of deur bestaande ekumeniese organisasies; (v) Deelnemers: alle gelowiges, die kerkhiërargie/leiers, afgevaardigdes van gemeentes/groepe, en/of verteenwoordigers van sekulëre owerhede; (vi) Wie neem leiding en die voorsitterstoel? Kerkleiers of verkose lede (geordendes, gewone lidmate); (vii)Aard van die konsultasie en die gesag van besluite: leerstellige sake, wetlike sake, hervorming/vernuwing, kerk-staat verhoudinge, handhawing van eenheid; (viii) Prosedures: reglemente vir orde, metodes (werkgroepe, kommissies), wyses waarop die konsilie afgesluit word.

Die Rustenburg Kerkeberaad van November 1990 kan as 'n goeie voorbeeld dien van hoe bogenoemde riglyne werk. Die Rustenburgberaad was weliswaar nie 'n konsilie nie, maar slegs 'n nasionale konferensie vir kerke. Dit is egter die mees verteenwoordigende amptelike kerkevergadering wat tot op hede nog in Suid-Afrika gehou is met 230 kerkleiers van 80 denominasies - verteenwoordigend van $90 \%$ van die Christendom in Suid-Afrika en ongeveer $70 \%$ van die totale bevolking. Die kerkleiers het ontmoet met die oog op gesamentlike getuienis in 'n veranderende Suid-Afrika ${ }^{62}$. Die sake wat in ag geneem moet word vir die byeenroep van 'n konsilie het ook gefigureer by die byeenroep van die Rustenburgberaad, byvoorbeeld: die krisis in Suid-Afrika het die geleentheid (kyk (i)) genoodsaak. Dit was 'n landswye (ii) beraad. Heelwat debat is gevoer oor wie die sameroeper (iv) van die beraad moes wees. Die inisiatief het van die Staatspresident uitgegaan wat so 'n beraad voorgestel het en dr Louw Alberts opdrag gegee het om dit te probeer fasiliteer. Die Suid-Afrikaanse Raad van Kerke was geneë om te vergader, maar sou slegs deelneem as hulle self as sameroepers optree. Die Staatspresident het toe die grootmoedigheid aan die dag gelè en teruggetree as sameroeper ${ }^{63}$. Die deelnemers $(v)$ het kerkleiers en leiers van parakerklike organisasies ingesluit. Daar moes ook besluit word wie die voorsitterstoel (vi) moet inneem. Die Suid-Afrikaanse Raad van Kerke het dr Alberts, 'n natuurwetenskaplike en gewone lidmaat, voorgestel as 'n versoenende gebaar met Frank Chikane as medevoorsitter. Een van die prosedures (viii) waarop besluit moes word is dat besluite op ' $\mathrm{n}$ basis van konsensus geneem word. $\mathrm{Na}$ al hierdie omsigtige voorbereiding het hierdie beraad met dit wat daar gebeur het, ' $n$ permanente plek in die kerke in Suid-Afrika se geskiedenis verwerf en ook die toekoms in 'n groot mate beïnvloed.

Om saam te vat: Konsiliêre gemeenskap as model vir kerkeenheid behels die sigbare, organiese eenheid van plaaslike kerke op elke plek en op alle plekke. Dit is dus veel meer as konsultasie met die oog op vreedsame naasbestaan of gesamentlike aksie. Dit is ' $n$ model wat regniatige verskeidenheid beskerm binne ' $n$ raamwerk van volle nagmaalsgemeenskap en 'n gesamentlike belydenis/erkenning van die apostoliese geloof 64 . Die aanloklike van die model is dat dit reg laat geskied aan die eenheid van die plaaslike kerk sonder om die universele/ekumeniese kerk uit die oog te verloor. 
Hierdie model het sy oorsprong in die insigte en ervaring van die internasionale bilaterale dialoë tussen die konfessies en kom ook voort uit die geledere van die konfessionele ekumeniese wêreldliggame. Die model plaas, soos die vorige modelle, ook die klem op die een apostoliese geloof, een doop, een nagmaal, en die wederisydse erkenning van die bedieningsvorme. Die andersheid lê daarin dat hierdie model die konfessionele identiteite en tradisies as legitieme uitdrukkingsvorme van die diversiteit van die kerk erken. Dit was ook die standpunt van die algemene sekretarisse van die konfessionele ekumeniese wêreldliggame tydens hulle vergadering in 197465. Die verskeidenheid word versoen as hulle werk om die verskille van die verlede te oorkom en aanvaarding toon vir mekaar se verskillende style. Die konfessies moet behou word as verwysingspunte binne 'n groter Christelike identiteit. Sommige aanhangers van die model glo die identiteite sal langsamerhand verander. Ander glo weer dat die konfessionele identiteite naas mekaar moet bly voortbestaan - hulle kan teologies versoen word, maar moet institusioneel afsonderlik bly66. Die Lutherse Wêreldfederasie het "versoende verskeidenheid" as model aanvaar tydens hulle vergadering in 1977 in Dar-esSalaam.

"Gemeenskap van gemeenskappe"

Hierdie model is 'n variasie op die "versoende verskeidenheid" model en spruit uit die bi-laterale dialoog tussen die Anglikaanse en Rooms Katolieke Kerk in die vroeë tagtigerjare ${ }^{67}$. Die model is voorgestel deur Kardinaal Jan Willebrands wat tot onlangs aan die stuur was van die Vatikaan se Sekretariaat van Eenheid. Kerkeenheid word hiervolgens gevisualiseer as 'n pluraliteit van tipes binne die een kerk van Christus wat in gemeenskap met mekaar leef68. Elke gemeenskap (tipe), behou sy eie teologiese metode, spiritualiteit en liturgie. Eenheid in geloof, nagmaal, bedieningsvorme en erkenning van die pous voorsien die basis vir die eenheid ${ }^{69}$.

\subsection{Eenheid as solidariteit}

Eenheid as solidariteit is 'n relatief nuwe model wat uit die eksistensiële ervaringe van die kerk in Latyns-Amerika spruit. Een van die voorstaanders van hierdie model, die Argentynse teoloog José Miguez-Bonino sien die groot skeidingsfaktor tussen die Christene nie as die onderskeie denominasies nie, maar tussen diegene wat volgens hom verkeerdelik glo dat geloof slegs 'n privaat aangeleentheid is en die wat glo dat geloof die kerk na buite moet rig om veral onreg aan te spreek. Die kerk moet veral solidariteit toon met die armes, die onderdruktes en die opsygeskuifdes van die samelewing - aldus Sobrino, 'n Rooms Katolieke teoloog in SuidAmerika 70 .

Elk van bogenoemde modelle het hulle sterk en swak punte. Best ${ }^{71}$ beoordeel die benaderings soos volg: "Organiese eenheid" en "konsiliêre gemeenskap" handhaaf die ekumeniese imperatief van een onverdeelde liggaam van Christus op aarde, maar moet nog heeltemal tot ' $n$ vergelyk kom met die waarde en funksie van die verskillende kerktradisies vir die liggaam van Christus. "Versoende verskeidenheid" en "gemeenskap van gemeenskappe" wil die beste neem wat elke 
tradisie bied, maar die gebrek aan 'n sterk oorkoepelende eenheidsvisie kan daartoe lei dat denominasionele verskille bloot versterk kan word. "Eenheid as solidariteit" herinner ons daaraan dat eenheid nie slegs 'n interne saak vir die kerk is nie, maar dat die eenheid ook die wêreld moet dien. My uitgangspunt is dat enige model vir eenheid tesame met die prioriteit van somatiese eenheid ook ruimte moet laat vir pneumatiese verskeidenheid. Die probleem met modelle twee tot vier is dat hulle al te maklik die verskillende kerktradisies gelykstel met die verskillende gawes van die Gees. Die modelle bring nie opklaring op die vraag waar regmatige verskeidenheid eindig en waar sondige verskeurdheid begin nie. Neuhaus 72 waarsku dat'n ekumeniese ideaal wat met min tevrede is, kontraproduktiewe ekumene kan wees, of soos hy dit stel "... ecumenism against itself". In hierdie opsig sluit Neuhaus by Pannenberg aan en beweer selfs dat die Wêreldraad van Kerke die primêre institusionele voorbeeld van kontraproduktiewe ekumene is ${ }^{73}$ deurdat die eenheidsgedagte as hoofaktiwiteit al meer agterweë gelaat is. 'n Verdere voorbeeld van kontraproduktiewe ekumene is Oscar Cullmann ${ }^{74}$ se idee van "Eenheid deur verskeidenheid" wat 'n gemeenskap van harmonieus geskeide kerke voorstaan. Niks minder as volle gemeenskap in Christus met God en met mekaar behoort altyd die einddoel van die ekumeniese strewe te bly nie. Ratzinger ${ }^{75}$ se formulering vat die insigte van die verskillende modelie goed saam: "The unity of the Church is the unity of Christians. The real goal of all ecumenical efforts must of course remain the transformation of the plural of confessional Churches separated from one another into the plural of local Churches that are in their diversity really one Church".

STRUIKELBLOKKE OP PAD NA DIE DOEL

Met 'n doel voor oë is die volgende stap om te bepaal waar die kerk waaraan jy behoort, staan ten opsigte van daardie doel. Breedweg gesproke kan 'n kerk hom in een van vyf stadia ${ }^{76}$ bevind in verhouding tot ander kerke: (i) Wedersydse uitsluiting, kompetisie en selfs vyandigheid; (ii) Ongeërgde naasbestaan - ander kerke se reg tot bestaan word erken maar elke kerk doen sy eie ding sonder om die ander kerke in ag te neem; (iii) Beperkte samewerking in sake van belang; (iv) Lidmate van die verskillende kerke doen soveel as moontlik saam as lede van dieselfde liggaam; (v) Volle gemeenskap.

Daar is 'n hele aantal redes waarom kerke vasgevang bly in die eerste stadium van eksklusiewe selfgenoegsaamheid. Een van die redes is die siening dat "ons" kerk die volle waarheid in pag het. Omdat die waarheid nie by "hulle" is nie, is verdagmakery en selfs proselietmakery aan die orde van die dag. Indien ekumeniese kontak op die agenda kom, funksioneer dit in hierdie en die volgende stadium slegs tussen eendersdenkendes. Diegene wat enigsins kans sien vir ekumeniese kontak met andersdenkendes, sien dit slegs as 'n geleentheid om te getuig van die waarheid wat ons het (lees: "besit") sonder om ruimte te laat dat ander ook teenoor ons kan getuig. Hierteenoor behoort Bavinck ${ }^{7}$ se woorde so 'n kerk te genees van enige pretensie dat ons kerk of gemeente die volle waarheid in pag het: "Indien wij daarom weer naar het Nieuwtestamentisch spraakgebruik onder kerken de plaatselijke kerken in de gansche Christenheid verstaan, dan zijn er geen ware en geen valsche kerken in volstrekten zin. Eene kerk is eene vergadering van warc Christgeloovigen op eene bepaalde plaats... indien het woord Gods op een bepaalde 
plaats nog eenigermate bekend is, zal het zekerlijk zijne werking doen en is er eene kerk van Christus, hoe onzuiver en vermengd dan ook. Daarmede wordt geen indifferentisme en syncretisme bedoeld. Onverschillig is er niets,... Er is groot verschil in de zuiverheid van de belijdenissen en de kerken. En naar de zuiverste hebben wij te staan en te streven". Hierdie strewe na 'n suiwerder waarheid word nie bereik deur 'n steriele gesprek van eendersdenkendes nie. As kinders van dieselfde Vader moet ons almal met mekaar gesels oor hoe ons die Vader (en Seun en Heilige Gees) ken en beleef en hoe ons die Skrif verstaan. Ons mag mekaar selfs (wederkerig) vermaan om sy wil te doen. Teologiese ooreenstemming kan dus nie die voorwaarde vir ekumeniese gesprek wees nie en die volgende standpunt van Treurnicht wys homself dus as onhoudbaar uit: "As mense die grondslae van ons geloof nie aanvaar nie, kan hulle nie sonder meer as broeders aanvaar word nie en kan daar ook geen broederlike gesprek met hulle wees nie. Sodanige gesprek vind slegs plaas tussen broeders wat dieselfde wedergebore lewe deelagtig is en dieselfde grondwaarhede onderskryf"78.

'n Tweede verkeerde grondhouding wat kerke vasgevang hou in stadium een, is die valse teenstelling tussen eenheid en waarheid. Voorstanders van dié standpunt sê ons moet kies tussen eenheid of waarheid. Dit is die een of die ander. Tog moet 'n mens nie uit die oog verloor nie dat die eenheid en die liefde déél uitmaak van die waarheid van die evangelie. As jy die eenheid verloor het, het jy daarmee saam 'n groot stuk van die waarheid prysgegee ${ }^{79}$. Ons moet waak teen die sonde teen die waarheid (heresie) en die sonde teen die liefde (schisma) ${ }^{\mathbf{8 0}}$. Eenheid en waarheid is dus soos die twee vlerke van 'n vliegtuig - die een kan nie sonder die ander nie. Ons sal die kreatiewe spanning moet lewend hou tussen die twee opdragte van die kerk, naamlik om én te wees en om die waarheid vas te hou. Dit gaan dus nie om eenheid of waarheid nie, of selfs nie om eenheid in waarheid nie, maar primêr om eenheid én waarheid. Hierdie stelling word onderstreep deur Biskop Brent ${ }^{81}$ wat reeds in 1927 tydens die Lausanne byeenkoms van "Faith and Order" gesê het: "We are seeking here for unity and truth, if possible truth in unity and if it must truth without unity". Juis in die eenheid kan ons saam soek na en getuig van die waarheid.

Die ekumeniese strewe is dus daardie behoefte om die gaping te vul tussen daar waar die kerke hulle op die ekumeniese pad bevind en die gesamentlike doel wat die kerke voor oë het ('n model vir kerkeenheid). In die praktyk vra dit van die plaaslike kerke om strategieë uit te werk om stap vir stap te vorder op die weg na eenheid. Hoewel totale eenheid die einddoel bly, moet die pad met nederigheid en realisme aangepak word sodat die kerke wat saam op weg gaan nie gedemoraliseer word as daar oënskynlik onoorkomelike struikelblokke opduik nie.

\section{NOTAS:}

1 D Guthrie, New Testament Theology, Leicester 1981, 743.

2 Ras, volk en nasie en volkereverhoudinge in die lig van die Skrif, Kaapstad 1975, 36.

$3 \quad$ Guthrie, $a w, 743$

J J F Durand, Una Sancta Catholica in sendingperspektief, Amsterdam 1961, 
38-39, 103.

5 Durand, $a w, 40$ en 104.

6 W D Jonker, "Die eenheid van die kerk - noodsaak of luukse?", in: Die eenheid van die Kerk van Christus, (C F A Borchardt (red)), NGKB 1987; (UPTS 3), 42-43. Vir 'n Rooms Katolieke en Ortodokse perspektief hierop, sien A Keshishian, Conciliar fellowship. A common goal, Geneva 1992, 30-32 en 117-118.

7 Durand, $a w, 16$.

8 Jonker, $a$ w, 35. Kyk ook Ras, volk en nasie..., a w, 50 no 34.

9 H Bavinck, Gereformeerde Dogmatiek, Deel vier, Kampen 1930, 300-301.

10 J A Heyns, "Die kerk se ekumeniese roeping", in: Die Ned Geref Kerk en sy ekumeniese verhoudinge (Onder redaksie van $\mathrm{P}$ B van der Watt), Pretoria 1983, 81. Kyk ook J A Heyns, "Die Ned Geref Kerk en die ekumene" in: Fokus op die kerk (Onder redaksie van P G J Meiring \& S J Joubert), Vereeniging 1992, 61.

11 Bavinck, $a w, 304$.

$12 \mathrm{~J}$ T Chao, "The nature of the unity of the local and universal church in evangelism and church growth", in: Let the earth hear his voice. International Congress on World Evangelization, Lausanne, Switzerland (Edited by J D Douglas), Minneapolis 1975, 1112.

13. Chao, $a w, 1108$.

14 D J Bosch, The local church in a changing South Africa, Ongepubliseerde toespraak, Pretoria 1990, 1.

15 Het geheim van de gemeente. Handreiking aan het voortgaande geloofsgesprek, aanvaard door de generale synode van de Nederlandse Hervormde Kerk in haar vergadering op 18 Juni 1974, 's-Gravenshage 1974, 38.

$16 \quad$ Het geheim van de gemeente, $a$ w, 38.

17 A G S Gous, "Plaaslike ekumene. 'n Strategiese beplanning", ISWENKommunikasie vol 14/1 (1992), 17.

18 Chao, $a w, 1108$.

19 J W de Gruchy, "Reflections on dialogue between the Afrikaans and English speaking churches", Ned Geref Teol Tydskrif vol 15/2 (1974), 124.

20 Bosch, $a w, 1-5$; A G S Gous, "Fokus op die Ned Geref Kerk binne die ekumeniese toneel in Suid Afrika", Skrif en Kerk vol 10/2 (1989), 139; Gous, ISWEN-Kommunikasie vol 14/1 (1992), 15 ; J A Heyns, "Gee die lidmate 'n 
kans om saam te praat oor kerkeenheid", Die Kerkbode vol 150 (3 April 1992), 5 ; P G J Meiring, "Eksklusief of ekumenies?", in: Venster op die kerk (PU vir CHO, Reeks F3:12), Potchefstroom 1980, 212; P G J Meiring, "Die Ned Geref Kerk en die baie ander kerke in ons land", in: Fokus op die kerk (Onder redaksie van P G J Meiring \& S J Joubert), Vereeniging 1992, 47-48; P Rossouw, Ekumeniese verkenning, Bloemfontein 1987, 64-68, om net enkeles uit die geledere van die NG Kerk te noem.

21 Bosch, $a w, 1$.

22 A G S Gous \& P G J Meiring, 'n Werkswinkel oor die NG Kerk se ekumeniese beleid en praktyk. Plaaslike ekumene in ring en gemeente, Ongepubliseerde dokument 1992, 10.

23 A Keshishian, Conciliar fellowship. A common goal, Geneva 1992, 24.

24 Aangehaal in Keshishian, $a w, 25$.

25 Keshishian, $a w, 26-30$.

26 Keshishian, $a w, 27-29$.

27 T van der Walt, "Die eenheid van die kerk van Christus in Suid-Afrikaanse perspektief", in: Die eenheid van die kerk van Christus, (C F A Borchardt (red)), NGKB 1987; (UPTS 3),25-26.

28 Het geheim van de gemeente, a w, 39.

29 Jonker, $a$ w, 41-42.

30 E Sullivan, "'Koinonia' as meta-model for future church unity", Ecumenical Trends vol 18/1 (1989), 1.

31 Gous, ISWEN-Kommunikasie, vol 14/1 (1992), 15-16.

32 WRK, "Papers and report on the unity of the Church", Faith and Order Paper no $77,1976,64$.

33 H Legrarde, "Councils of Churches as instruments of unity within the one Ecumenical movement", in: Instruments of unity (Edited by T F Best), Geneva 1988, 56.

34 M Ruokanen, Hermeneutics as an ecumenical method (in the theology of Gerhard Ebeling), Helsinki 1982, 9; Kyk ook die konstitusie van die Wèreldraad van Kerke (III:1) in "Rules, Bylaws..." Geneva 1987, 1.

$35 \quad V$ ir die volledige verklaring: "The church, the churches and the World Council of Churches", kyk L Vischer (red), A documentary history of the Faith and Order movement 1927-1963, St Louis, MO 1963, 167-176.

$36 \quad$ T F Best, "Models of unity", One World vol 132 (1988), 12. 
L A Hoedemaker, "Conciliaire gemeenskap of kerk van de armen", in: Praktische Theologie (Onder redaksie van C P van Adel Azn, A Geerse, L A Hoedemaker), 's-Gravenshage 1980, 169.

38 L Hodgson, The second world conference on Faith and Order held at Edinburgh, August 3-18, 1937, New York 1938, 250-269 aangehaal in Crow, Mid-Stream vol 27/2 (1988), 125.

39 R Keeley (red), An Eerdmans Handbook: Christianity in todays world, Grand Rapids, MI 1985, 93-95.

40 W A Visser't Hooft, The New Delhi Report: the Third World Assembly of the World Council of Churches, 1961, New York 1961, 116.

41 P A Crow, "Reflections on models of Christian unity", Mid-Stream vol 27/2 (1988), 123.

42 Best, One World vol 132 (1988), 12.

43 N Goodall, Uppsala '68 Speaks, Geneva 1968, 13.

44 Crow, Mid-Stream vol 27/2 (1988), 126-127.

45 Aangehaal in Crow, Mid-Stream vol 27/2 (1988), 127.

46 J C Marais, "Proposals for the proces of church unification", Theologia Viatorum vol 18 (1990), 84-85 ; A R Mickelson, "Unity in an intraconfessional context", in: Living today towards visible unity (Edited by T F Best), Geneva 1988, 87-98.

47 Marais, Theologia Viatorum vol 18 (1990), 81-84.

48 NRC/RCN/ELC, "Progress in unification process", Uniting vol 3 (Oct 1992), $1-2$.

49 A-L Van Renen, Russel Botman, "Ek is 'n kronies gelowige mens", Die Kerkbode vol 150 (6 November 1992), 6.

50 Acta Algemene Sinode 1990, Ekumeniese beleid, Bloemfontein 1990, 548 no 1.5.3.

51 Keshishian, $a w, 21$.

52 Ruokanen, $a w, 12-13$.

53 Report of the Salamanca Consultation, "The unity of the church - Next steps", in: What kind of unity (Faith and Order paper 69), Geneva 1974, 121.

54 Crow, Mid-Stream vol 27/2 (1988), 128.

55 T F Best, Instruments of unity. National Councils of Churches within the one ecumenical movement, Geneva 1988, 128-138 ('n dokument van 1975 van die 
Rooms Katolieke Sekretariaat van Eenheid); Keshishian, $a$ w, xiii-xiv, 1-5; en die Report of the Salamanca Consultation, $a w, 121-2$.

56 Report of the Salamanca Consultation, $a w, 121$.

57 D M Paton (red), Breaking barriers: Nairobi 1975, official report of the fifth assembly of the WCC, London \& Grand Rapids, MI 1976, 60.

$58 \quad$ Keshishian, $a w, 19$.

59 M Kinnamon (red), Signs of the Spint: Official report, Seventh Assembly, WCC, Canberra, Geneva \& Grand Rapids MI 1991, 173.

60 K S Hurty, "Marks of local ecumenism: Vision for the 1990's", Ecumenical Trends vol 19/3 (1990), 12.

61 "Councils, conciliarity and a genuinely universal council", Faith and Order paper no 70 , Geneva 1974,8 .

62 L Alberts \& F Chikane (reds), The road to Rustenburg, Kaapstad 1991, 10.

63 Alberts \& Chikane, $a w, 14$.

64 Keshishian, $a w, 71$.

65 Best, One World vol 132 (1988), 12-13; Crow, a w, 129.

66 Keshishian, $a w, 64$.

67 K Raiser, "Modelle kirchlicher Einheit. Die Debatte der siebzicher Jahre und die Folgerungen für heute", Ökumenische Rundschau vol 36/2 (1987), 208.

68 Best, One World vol 132 (1988), 13.

69 Keshishian, $a w, 65$.

$70 \quad$ Best, One World vol 132 (1988), 13.

71 Best, One World vol 132 (1988), 13.

72 R J Neuhaus, "Ecumenism against itself", Theology Digest vol 35/4 (1988), 327-337.

73 Neuhaus, Theology Digest vol 35/4 (1988), 334,337.

74 O Cullmann, Unity through diversity, Philadelphia 1988, 35-36. Kyk ook Neuhaus, Theology Digest vol 35/4 (1988),330 en Sullivan, Ecumenical Trends vol $18 / 1(1989), 4$.

75 J Ratzinger, Church, ecumenism and politics, New York 1988, 119-120.

76 Neuhaus, Theology Digest vol 35/4 (1988), 329-330. 
77 Bavinck, $a w, 303$.

78 A P Treurnicht, Op die keper, Kaapstad 1964, 145.

79 P G J Meiring, "Die Ned Geref Kerk en die baie ander kerke in ons land", in: Fokus op die kerk (Onder redaksie van P G J Meiring \& S J Joubert), Vereniging 1992, 45-46. Vir 'n Skriftuurlike begronding vir die ekumene, sien: W Nicol, "Church unity and diversity in the New Testament", in: Church unity and diversity in the Southern African context (Onder redaksie van W S Vorster), Pretoria 1980, 1-18. Vir 'n dogmatologiese begronding vir die ekumene - Kyk: C J Wethmar, "Ekumenisiteit in dogmatologiese perspektief", Skrifen Kerk vol 13/1 (1992), 96-110.

80 Jonker, $a w, 37-38$, en Bavinck, $a w, 304$.

81 Aangehaal deur B J Marais, "Die kerk in die kontemporêre wêreld", in: A Geyser (et al), Vertraagde Aksie, Uitgegee deur die skrywers 1960, 38. 